\title{
Silence Is Golden: Excluding Internal Complaints from ERISA Section 510
}

\section{INTRODUCTION}

Imagine you are an employee who has just been terminated from her job. Two days before, you complained to management concerning various ERISA violations you believe the company made. You are certain that you were fired in retaliation for these complaints. Conversely, imagine you are an employer who has just eliminated an employee with a history of inappropriate behavior in the workplace. Previously, when you confronted the employee about his bad behavior, he remarked, "Where do you get off judging me when you are lying to us about the cost of our insurance!" You shake off the comment and fire him two days later. You subsequently receive notice that the troublesome employee is now suing your company for retaliatory discharge.

These two hypotheticals highlight the issues involved in a growing circuit split surrounding the proper interpretation of section 510 of the Employee Retirement Income Security Act (ERISA). ${ }^{1}$ Section 510

* Eli Rosenberg. J.D. candidate 2012, University of Kansas School of Law; M.B.A. 2009, Missouri State University; B.A. 2007, University of Kansas. I would like to thank the Kansas Law Review staff and board-in particular Alex Fehr and Melissa Plunkett-for their hard work during the editing process. Special thanks to Professor Thomas Brous, Jacob Gontesky, and Alex Aguilera for their invaluable feedback on earlier drafts. Finally, thank you to my friends and family for their support during the process of writing this Comment.

1. Section 510 of ERISA consists of three distinct clauses:

It shall be unlawful for any person to discharge, fine, suspend, expel, discipline, or discriminate against a participant or beneficiary for exercising any right to which he is entitled under the provisions of an employee benefit plan, this subchapter, section 1201 of this title, or the Welfare and Pension Plans Disclosure Act [29 U.S.C. § 301 et seq.], or for the purpose of interfering with the attainment of any right to which such participant may become entitled under the plan, this subchapter, or the Welfare and Pension Plans Disclosure Act. It shall be unlawful for any person to discharge, fine, suspend, expel, or discriminate against any person because he has given information or has testified or is about to testify in any inquiry or proceeding relating to this chapter or the Welfare and Pension Plans Disclosure Act. In the case of a multiemployer plan, it shall be unlawful for the plan sponsor or any other person to discriminate against any contributing employer for exercising rights under this chapter or for giving information or testifying in any inquiry or proceeding relating to this chapter before Congress.

Employee Retirement Income Security Act of 1974 § 510, 29 U.S.C. § 1140 (2006). This Comment 
protects an employee from discharge as a retaliatory act because she provided information, testified, or is about to testify in an inquiry or proceeding relating to ERISA violations. ${ }^{2}$ The split this section has caused in the circuit courts is indicative of the two competing desires of whistleblower statutes: (1) the protection and encouragement of employee rights on the one hand and (2) the desire to not hinder or constrict a company's management of its business operations on the other. Two circuits - the Fifth and the Ninth-have held that section 510 protects internal complaints to management. Three circuits - the Second, Third, and Fourth-appear to represent the majority view that these complaints do not fall within the purview of the statute because they are not a part of a formal inquiry or proceeding. While the majority circuits are correct-section 510 of ERISA does not protect internal complaints made to management - their reasoning is unsatisfying because it relies too heavily on the plain meaning of the terms inquiry and proceeding. A better explanation for why section 510 of ERISA does not protect informal complaints is found by making statutory interpretation one part of a broader analysis. First, by comparing section 510's antiretaliation provision with those of other federal statutes, one finds that Congress tailors these provisions specifically to achieve certain goals. Therefore, Congress knows how to protect from retaliation internal complaints made to management should it want to do so. Second, the exclusion of internal complaints from section 510's protection is bolstered by examining its legislative history and comparing it with the similar whistleblower provision contained within Title VII of the Civil Rights Act of $1964 .^{3}$ Finally, an explanation as to why Congress would not want to protect internal complaints can be gleaned by analyzing the underlying rights and interests protected by ERISA and balancing them against the interests of overburdened employers.

\section{BACKGROUND}

\section{A. Brief Overview of Whistleblowing}

Whistleblowing pits two generally accepted social values against one another: the employee's duty of loyalty and the individual's duty to

deals primarily with the second clause of section 510, as that is the subject of the circuit split.

2. Id.

3. 42 U.S.C. $\S 2000 \mathrm{e}-3(a)$. 
society. ${ }^{4}$ Whistleblower protection statutes are thus in the unenviable position of encouraging employees to take actions detrimental to their employers' interests. ${ }^{5}$ Statutes accomplish this by affirmatively protecting those employees from retaliation. ${ }^{6}$

Generally, these statutes serve a dual purpose of protecting the employee while simultaneously advancing a higher policy goal of the government. For example, although it did not affirmatively protect employees from retaliation, the False Claims $\mathrm{Act}^{7}$ passed after the Civil War sought to encourage employees to report the fraudulent practices their employers engaged in when dealing with the federal government. ${ }^{8}$ The Act was a precursor to modern antiretaliation protections and serves as an early example of the federal government actively encouraging lawsuits to police unscrupulous employers. However, the Act differed from modern antiretaliation statutes in its method of encouragement by only rewarding whistleblowers with a portion of the amount their employers owed to the government, as opposed to protecting the employees from retaliation. ${ }^{9}$ Even in this limited form, the Act helped Congress achieve its goal of encouraging employees to bring the wrongdoing of their employers to light. ${ }^{10}$

The Railway Labor Act of $1926^{11}$ represented the next evolution of whistleblower protection in the United States. ${ }^{12}$ The Act sought to curb employers' ability to prevent their employees from organizing by making it a misdemeanor offense to influence or coerce workers regarding their status as members of a labor organization. ${ }^{13}$ Like the False Claims Act before it, the Railway Labor Act helped advance a key congressional goal: protecting unionization by affirmatively shielding employees-to some extent-from retaliation by their employers. ${ }^{14}$ In contrast with

4. Daniel P. Westman \& Nancy M. Modesitt, Whistleblowing: The LaW of RETALIATORY DisCHARGE 2-4 (2d ed. 2004).

5. Id. at 3 .

6. Id.

7. False Claims Act, ch. 67, 12 Stat. 698 (1863) (codified as amended at 31 U.S.C. §§ 37293733 (2006 \& Supp. III 2010)).

8. WESTMAN \& MODESITT, supra note 4, at 3-4.

9. See id.

10. Id.

11. Railway Labor Act, ch. 347, 44 Stat. 577 (1926) (codified as amended at 45 U.S.C. §§ 151188 (2006)).

12. WeSTMAN \& ModesitT, supra note 4, at 5-6.

13. Id. at 6.

14. See id. 
modern acts, however, the Railway Labor Act still provided little formal protection to employees making complaints against their employers. ${ }^{15}$

Serious protection for whistleblowing employees did not come about until the 1970s and 1980s. ${ }^{16}$ The expansion in protections coincided with growing public perception and awareness that businesses and industries were engaging in illegal or corrupt practices at increasing rates. ${ }^{17}$ This perception led to the passage of several federal acts including the Racketeer Influenced and Corrupt Organizations Act (RICO), ${ }^{18}$ designed to regulate and punish employers for engaging in illicit activities. ${ }^{19}$ Furthermore, the public's perception of widespread corruption in the leadership of the country was not limited to the private sector, as evidenced by the Watergate scandal that led to the resignation of thenPresident Nixon. ${ }^{20}$ The general public's loss in confidence of highly placed persons in both government and business "created a climate favorable to whistleblowing." 21

The ultimate ineffectiveness of statutes designed to curb illegal business practices helped further expand whistleblower protection. In the 1980s, despite the enactment of expansive federal regulations such as RICO, the general perception persisted that illegal activities of employers remained unregulated by the federal agencies charged with monitoring them. ${ }^{22}$ This in turn led to a significant increase in the whistleblowing movement as employees began acting in their capacity as individual employees to solve the problem of corporate crime rather than relying on the federal government. ${ }^{23}$ It was amidst this climate of social upheaval that Congress enacted ERISA in the 1970s.

\section{B. Balancing Interests: A Desire to Protect Employers}

In constructing whistleblower or antiretaliation statutes, legislators attempted to balance the need to encourage employees to report

\footnotetext{
15. See id. (stating that individual employees were not permitted to bring actions seeking to enforce the act)

16. Id. at $10-11$.

17. Id. at $9-10$.

18. Racketeer Influenced and Corrupt Organizations Act, Pub L. No. 91-452, 84 Stat. 941 (1970) (codified as amended at 18 U.S.C. §§ 1961-1968 (2006 \& Supp. III 2010)).

19. WestMan \& ModesitT, supra note 4, at 9.

20. Id.

21. Id. at 10 .

22. Id. at 11 .

23. Id.
} 
infractions with the interests of employers and managers in running their businesses without interference or state intrusion. ${ }^{24}$ Both in and out of the ERISA context, the protection and encouragement of whistleblowers presents a number of important challenges and concerns for employers. ${ }^{25}$ Chief among these concerns are the financial costs associated with whistleblowing and the effect whistleblowing has on workplace morale and culture. ${ }^{26}$

Financial costs associated with whistleblowing are a key interest of employers. Passing antiretaliation legislation creates financial burdens on employers in the form of both preventative and responsive costs. Preventative costs include substantial lost time due to training and creating hotlines, as well as other means of reporting violations and utilizing the company's remedial services. ${ }^{27}$ Furthermore, an organization facing a charge of unlawful retaliation must also bear the cost of investigating the charge, defending against the charge, and paying any damages awarded as a direct result of the charge. ${ }^{28}$ These costs are separate and apart from other costs to the organization that may be harder to quantify, such as negative publicity and lack of productivity. ${ }^{29}$

High costs are a concern for the employer because they are a financial burden and may encourage an opportunistic employee to bring an antiretaliation action in the hopes that the employer will settle rather than expend the time and money necessary to defend the suit. ${ }^{30}$ Similarly, leaving these costs unchecked may result in "too many whistles blowing."31 Poor-performing employees could bring false complaints to prevent their employers from "taking legitimate adverse actions against them."32

Whistleblowing can also have a negative impact on the internal relations of the organization. Conflicts can arise not just between the

24. Gina Oderda, Note, Opposition at the Water Cooler: The Treatment of Non-purposive Conduct Under Title VII's Anti-retaliation Clause, 17 DuKE J. GENDER L. \& POL'Y 241, 249 (2010).

25. See Mary Kreiner Ramirez, Blowing the Whistle on Whistleblower Protection: A Tale of Reform Versus Power, 76 U. CIN. L. REV. 183, 220 (2007).

26. See James Fisher et al., Privatizing Regulation: Whistleblowing and Bounty Hunting in the Financial Services Industries, 19 DICK. J. INT’L L. 117, 133-34 (2000).

27. See Ramirez, supra note 25, at 226.

28. Fisher et al., supra note 26, at 134.

29. See id.

30. See id. at 133-34 ("In the face of these risks to the organization, an opportunistic whistleblower is in an excellent position to extort a settlement from the employer.”).

31. See Ramirez, supra note 25, at 223.

32. Id. 
whistleblower and their employer but also between the whistleblower and their fellow employees as their coworkers try to either defend the whistleblower or the employer. ${ }^{33}$ Coworkers may feel resentment toward the whistleblower for disrupting the harmony of the group. For example, coworkers may resent the whistleblower for creating an investigation to oust employees who were just following orders from their superiors but were complicit in the violations. ${ }^{34}$

Looking specifically at the ERISA context, the primary cost to employers of whistleblower protection is likely the time and money spent answering legal claims. This is because ERISA contains substantial recordkeeping and reporting requirements for determining the exact benefits due to an employee. ${ }^{35}$ These records are often the only evidence available to an employee seeking to prove an ERISA violation. ${ }^{36}$ Thus, some of the common costs of whistleblower protection to employers do not apply in the ERISA context. For example, an investigation into a reported ERISA violation is likely to cost very little because all the information necessary to make a finding is available within the records. However, whistleblower protection still imposes high costs on employers, such as defending and paying judgments on suits brought under section 510 of ERISA and interfering with legitimate management decisions. ${ }^{37}$

The costs of whistleblower protection are important and necessary considerations for legislatures in constructing antiretaliation statutes. Explaining why this is the case requires further insight into the emergence of whistleblower provisions. Specifically, the desire to balance employer interests with public policy stems from the fact that antiretaliation provisions are an exception to the traditional rule of employment at will. The employment at will doctrine holds that employment is terminable by either party-employer or employee-at will. ${ }^{38}$ Furthermore, the relationship is severable with good cause, no

33. Fisher et al., supra note 26, at 133-34.

34. See Ramirez, supra note 25, at 224-25.

35. See 29 U.S.C. § 1059 (2006 \& Supp. III 2010) (listing the recordkeeping and reporting requirement of employers).

36. See Laborers' Pension Fund v. A \& C Envtl., Inc., 301 F.3d 768, 783 (7th Cir. 2002) (citing Brick Masons Pension Trust v. Indus. Fence \& Supply, Inc., 839 F.2d 1333, 1338 (9th Cir. 1988)).

37. See Winters v. Hous. Chron. Publ'g Co., 795 S.W.2d 723, 732 (Tex. 1990) (Doggett, J., concurring); Fisher et al., supra note 26, at 134.

38. Elletta Sangrey Callahan, The Public Policy Exception to the Employment at Will Rule Comes of Age: A Proposed Framework for Analysis, 29 AM. Bus. L.J. 481, 483 (1991). 
cause, or a morally reprehensible cause. ${ }^{39}$ The rationale behind the rule is one of mutual rights: "an employee who cannot be compelled to work may not compel an employer to employ him or her."40

A primary purpose of antiretaliation provisions is to ameliorate the harshness of the employment at will doctrine. ${ }^{41}$ These provisions, however, cannot accomplish this without also intruding on employers' traditional rights, including the right to decide whom that business employs. $^{42}$ Thus, courts have held that the public policy exception for whistleblowers should be tailored to achieve a dual purpose of not interfering with lawful employers making ordinary employment decisions and protecting those employees who risk their jobs to protect the public. ${ }^{43}$

\section{ERISA and Section 510}

ERISA was passed by Congress and signed into law in 1974 with important policy goals in mind. ${ }^{44}$ ERISA sought to regulate pension plans by ensuring that employees received the benefits they were promised. ${ }^{45}$ In doing so, it made the security of these promises a prominent federal goal. ${ }^{46}$

Pension plans such as those governed by ERISA are private in nature. The onus is on individual employees to make a number of key decisions regarding their investment: whether to participate, how to allocate funds, and when to withdraw those funds. ${ }^{47}$ The federal government's role in this pension system is purposely limited to providing tax incentives for contributions and the regulatory scheme of ERISA. ${ }^{48}$ This has led to the common three-legged stool allegory with

39. Id.

40. Id.

41. Jenny Mendelsohn, Note, Calling the Boss or Calling the Press: A Comparison of British and American Responses to Internal and External Whistleblowing, 8 WASH. U. GLOB. STUD. L. REV. 723, 724-25 (2009).

42. See Winters, 795 S.W.2d at 732 (Doggett, J., concurring).

43. Id.

44. Pub. L. No. 93-406, 88 Stat. 829 (1974); JAmes A. WoOten, The Employee Retirement INCOME SECURITY ACT OF 1974: A POLITICAL HistORY 1 (2004).

45. WoOTEN, supra note 44 , at 3.

46. Id.

47. Stephen F. Befort, The Perfect Storm of Retirement Insecurity: Fixing the Three-Legged Stool of Social Security, Pensions, and Personal Savings, 91 MiNN. L. REV. 938, 946 (2007). This is particularly true in the case of defined contribution plans, as opposed to defined benefit plans. Id.

48. Id. at $945-46$. 
pension plans as one part of the basis of people's retirement along with social security and personal savings. ${ }^{49}$

To increase the security of pension plans, Congress imposes numerous reforms and requirements with which employers had to comply. ${ }^{50}$ First, ERISA creates fiduciary standards of conduct for the plan administrators. ${ }^{51}$ These standards require plan managers to act only in the interest of plan participants and to exercise the requisite care, skill, and diligence necessary to perform their duties. ${ }^{52}$ Second, ERISA requires pension plans to comport with minimum vesting standards, forcing employers to give employees a legal right to the benefits after a period of time specified by statute. ${ }^{53}$ Third, employers must take steps to ensure that pension plans will meet their long-term obligations, including setting aside financial resources before employees retire and participating in an insurance program that pays out vested benefits if a plan cannot. ${ }^{54}$

These requirements create a set of duties with which employers must comply. Conversely, they also imbue the plan beneficiariesemployees-with rights. Section 510 protects employees against interference with these rights by allowing them to bring claims against their employer. ${ }^{55}$

More importantly, section 510 makes it unlawful to "discharge, fine, suspend, expel, or discriminate against any person because he has given information or has testified or is about to testify in any inquiry or proceeding [involving ERISA]." ${ }^{\text {56 }}$ This language is typical of other whistleblower protection statutes, such as the Civil Rights Act of 1964, and is commonly known as a "participation clause." 57 Whether internal complaints to management fall under the protection of ERISA's "participation clause" is the focal point of the circuit split. ${ }^{58}$

49. Vada Waters Lindsey, Encouraging Savings Under the Earned Income Tax Credit: A Nudge in the Right Direction, 44 U. Mich. J.L. REFORM 83, 83-84 (2010).

50. See WoOTEN, supra note 44, at 5 (listing ERISA reforms aimed at protecting employee pensions).

51. Id.

52. Id.

53. Id.

54. Id.

55. Christina A. Smith, Note, The Road to Retirement-Paved with Good Intentions but Dotted with Potholes of Untold Liability: ERISA Section 510, Mixed Motives and Title VII, 81 MINN. L. REV. 735, 743 (1997).

56. 29 U.S.C. $§ 1140$ (2006).

57. WESTMAN \& MODESITT, supra note 4, at 191-92.

58. Cristin Schmitz, No ERISA Whistleblower Protection for Unsolicited Internal Complaints, INSIDECOUNSEL, Sept. 1, 2010, at 74. 


\section{The Circuit Split}

1. The Minority View

The two minority circuits were the first to analyze whether ERISA section 510 covers internal complaints to management. Both decided in the affirmative. However, the Ninth Circuit was the only one to provide detailed reasoning. The foundation of the minority circuits' reasoning, and the entire basis of the Ninth Circuit's decision, is that failing to protect internal complaints from retaliatory discharge leads to problematic results and defeats the purpose of the statute. In short, if internal complaints to management are not protected, unscrupulous employers too easily circumvent the purpose of section 510 .

In Hashimoto v. Bank of Hawaii, the Ninth Circuit became the first to address whether making internal complaints to management about ERISA violations is a protected activity under section $510 .^{59}$ The employee, Hashimoto, sued her former employer alleging retaliation for making several internal complaints regarding potential or actual ERISA violations by her employer. ${ }^{60}$ Specifically, she had complained that her supervisor had told her to "recalculate a former employee's pension plan" benefits using final pay rather than average pay-a violation of ERISA regulations. ${ }^{61}$ Hashimoto subsequently sued for wrongful discharge in violation of Hawaii's Whistle Blowers' Protection Act. ${ }^{62}$ The Ninth Circuit found that this claim was preempted by ERISA because ERISA contains a provision specifically designed to protect whistleblowers such as Hashimoto. ${ }^{63}$

The court in Hashimoto found that section 510 of ERISA protects a plaintiff who makes an internal complaint if the complaint is "protesting a violation of law in connection with an ERISA plan." 64 Interestingly, the court explicitly found that internal complaints of the kind Hashimoto made met the statutory requirement of being a part of an inquiry or proceeding. ${ }^{65}$ The first step in providing information or testifying in a way that may tempt an employer to discharge an employee would be to

\footnotetext{
59. 999 F.2d 408 (9th Cir. 1993).

60. Id. at 409.

61. Id. at 410.

62. Id. at 409.

63. Id. at 412.

64. Id. at 411.

65. Id.
} 
first present the problem to the responsible ERISA managers within the company. ${ }^{66}$ If an employer discharges an employee who has made internal complaints, the process of providing information or testifying is circumvented from the outset because "the anticipatory discharge discourages the whistle blower before the whistle is blown." ${ }^{\circ 7}$ In other words, if section 510 of ERISA did not protect internal complaints to management, employers would be able to evade the section's purpose by eliminating a whistleblower before he has a chance to blow the whistle. Therefore, according to the Ninth Circuit's reasoning, section 510 of ERISA protects internal complaints to management.

This interpretation of ERISA's whistleblower statute is in line with the social climate that led to increased whistleblower protection in the 1970 s and 1980s. ${ }^{68}$ Individuals are encouraged to act rather than rely on government agencies and regulations to oversee and correct violations. The interpretation clearly favors the employee's interests in enforcing her rights over the employer's interests in running its business unencumbered. This interpretation further assumes that this must have been Congress's intent.

In Anderson v. Electronic Data Systems Corp., the Fifth Circuit was the next to decide whether section 510 of ERISA protects internal complaints. $^{69}$ Anderson's position with the defendant employer placed him in charge of investments for all domestic short- and long-term pension portfolios. ${ }^{70}$ Anderson alleged retaliation for his refusal to commit illegal acts and for reporting the inappropriate conduct of a fellow employee. ${ }^{71}$ Specifically, Anderson alleged his employer asked him to sign payment invoices on behalf of the portfolios under his control-portfolios which his fellow employee had retained without the approval of the pension trustees. ${ }^{72}$ Performing this action is a clear violation of ERISA. ${ }^{73}$ Additionally, Anderson's employer asked him to write up minutes for meetings on the company's retirement planmeetings Anderson did not attend. ${ }^{74}$ Anderson asserted that he both

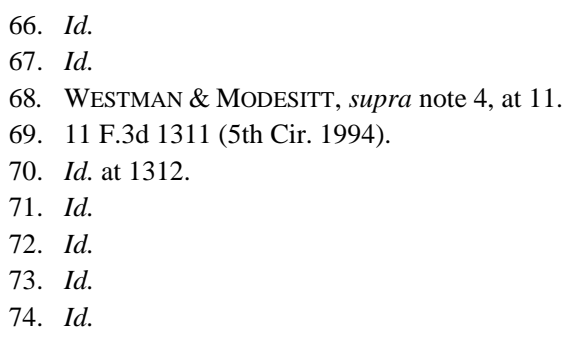


refused to commit the illegal acts and reported the incidents and improper conduct of his fellow employee to management. ${ }^{75}$ Soon thereafter, Anderson's employer fired him. ${ }^{76}$ Anderson sued alleging wrongful discharge because in Texas, "employment-at-will contracts cannot be terminated because of the employee's refusal to commit illegal acts." 77

The Fifth Circuit, like the Ninth, first addressed whether ERISA preempted Anderson's state law cause of action. ${ }^{78}$ The court concluded that ERISA preempted Anderson's state law cause of action because the claim directly related to ERISA and would conflict with federal law. ${ }^{79}$ Furthermore, the Supreme Court had previously held that ERISA's preemption power was purposely expansive and was to be interpreted broadly. ${ }^{80}$

Interestingly, the court in Anderson glossed over the internal complaints issue, stating simply that "ERISA $\S 510$ broadly prohibits the termination or other adverse treatment of participants and beneficiaries." ${ }^{\prime 1}$ Therefore, Anderson's cause of action fell within the scope of ERISA's civil enforcement provision. ${ }^{82}$ In so holding, the court effectively treated the eventual issue of a significant circuit split as a nonissue. The court did not even cite to Hashimoto - the case that only one year before resolutely held that section 510 of ERISA protects this activity. $^{83}$

It is possible that the Fifth Circuit's broad treatment of section 510 stemmed from its analysis of ERISA's preemption provision. Namely, because the Fifth Circuit had previously held that the preemption provision of ERISA was " "to be construed extremely broadly," " ${ }^{84}$ other provisions of ERISA were to be given similarly expansive treatment. However, because the Fifth Circuit opinion did not explain its reasoning

75. Id. at 1313.

76. Id.

77. Id. (citing Sabine Pilot Serv., Inc. v. Hauck, 687 S.W.2d 733, 735 (Tex. 1985)).

78. Id.

79. Id. at 1314 .

80. Id. at 1315-16 (citing Christopher v. Mobil Oil Corp., 950 F.2d 1209, 1217 (5th Cir. 1992)).

81. Id. at 1315.

82. Id.

83. See id. (holding that internal complaints are protected by ERISA's civil enforcement provision, without reference to Hashimoto).

84. Id. at 1316 (quoting Corcoran v. United Healthcare, Inc., 965 F.2d 1321, 1328 (5th Cir. 1992), abrogated on other grounds by Mertens v. Hewitt Assocs., 508 U.S. 248, 255 (1993), as recognized by Rogers v. Hartford Life \& Accident Ins. Co., 167 F.3d 933, 944 (5th Cir. 1999)). 
for a broad interpretation of section 510, one is left to assume that the court did not view it as an issue worth addressing.

Thus, the Ninth and Fifth Circuits were the first to address the issue of whether section 510 of ERISA protects internal complaints, and both concluded in the affirmative. The Fifth Circuit apparently gave this issue little consideration, assuming that the section was broad in nature and meant to cover internal complaints. The Ninth Circuit, on the other hand, provided far more insight into its reasoning. Specifically, if section 510 of ERISA does not protect internal complaints, then the entire section is without purpose because employers could end whistleblower litigation before it begins. This appeared to be the definitive case on the issue until King v. Marriot International, Inc., ${ }^{85}$ when the Fourth Circuit initiated the split.

\section{The Majority View}

The majority circuits made their decisions after the minority circuits. Each majority circuit decision built upon the reasoning and holding of the previous one. The Fourth Circuit rejected internal complaints from section 510 protection because such complaints did not rise to the level of formality required by that statute. Similarly, the Second Circuit also found that internal complaints did not fit the plain language of section 510 of ERISA, although the court did provide a broader interpretation of the term inquiry to cover the informal gathering of information by employers. Thus, if an employer contacts an employee, section 510 protects what the employee says. Finally, the Third Circuit recounted every case involved in the split and found the reasoning of the Second Circuit to be the most persuasive because section 510's unambiguous language did not protect internal, unsolicited complaints to management.

In King, the Fourth Circuit became the first to hold that internal complaints to management are not protected under ERISA's whistleblower statute. ${ }^{86}$ The facts of the case were similar to those of Hashimoto and Anderson. The plaintiff, King, worked in the defendant's benefits department for several years and had a reputation as an excellent employee. $^{87}$ In late 1998, she learned that the Senior Vice President of Compensation and Benefits for the company, defendant Fredericks,

85. 337 F.3d 421 (4th Cir. 2003).

86. See id. at 428 .

87. Id. at 423. 
planned to transfer millions of dollars from Marriott's medical plan to its general corporate reserve account. ${ }^{88}$ King felt the transfer was inappropriate and expressed her concerns to both coworkers and Fredericks. $^{89}$ Despite King's misgivings about the proposed transfer, Fredericks promoted her in late $1999 .{ }^{90}$ Fearing that the transfer was a violation of ERISA, King registered complaints with both Fredericks and two in-house attorneys. ${ }^{91}$ She even requested an opinion letter from one of the attorneys on the appropriateness of the transfer. ${ }^{92}$ Subsequently, Fredericks restructured the responsibilities of King's department, dividing authority between King and another employee. ${ }^{93}$ This led to a feud between King and the other employee, a feud that substantially affected the performance of the entire benefits department. ${ }^{94}$ Marriott again proposed a transfer of funds, and King once again objected, verbally and in writing, to Fredericks. ${ }^{95}$ Finally, Fredericks terminated both King and her feuding coworker, asserting that their continuing feud was hampering the operation of the department. ${ }^{96}$ King then sued Marriott. ${ }^{97}$

In analyzing whether section 510 provides a remedy for King's claim, the court focused on the "inquiry or proceeding" language of the provision. ${ }^{98}$ The court reasoned that the term proceeding does not apply to intra-company complaints but rather refers to administrative or legal actions. $^{99}$ The court further reasoned that the term testify connotes a level of formality that does not include an employee's oral complaint to his supervisor. ${ }^{100}$ The court noted that the antiretaliation provision of ERISA, like the Fair Labor Standards Act (FLSA), contains narrower language than that found in other federal whistleblower statutes. ${ }^{101}$ Therefore, the court found that the terms inquiry and proceeding are both

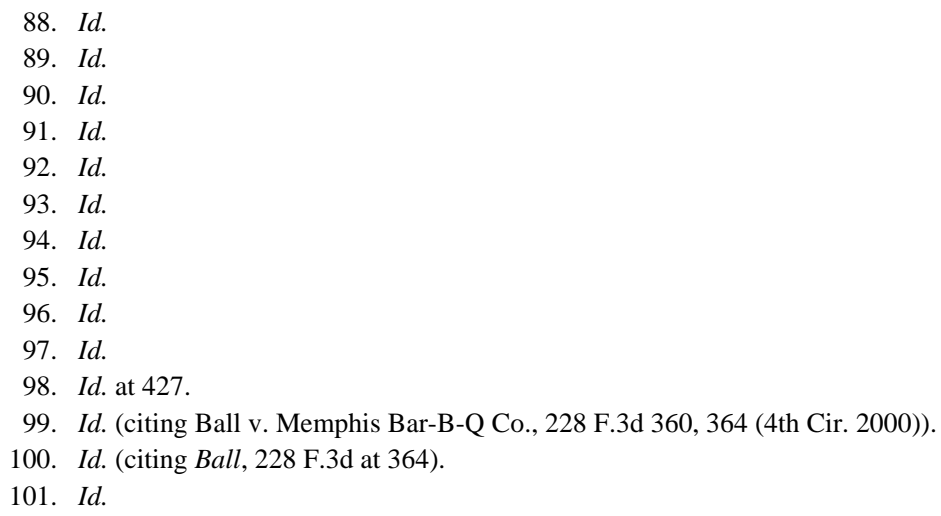


limited to legal or administrative actions. ${ }^{102}$ At the very least, the terms require "something more formal than written or oral complaints made to a supervisor."103

Applying that reasoning to the King case, the court found that the plaintiff did not allege that she had been terminated because she had testified, or was about to testify, in any proceeding. ${ }^{104}$ Rather, she had merely alleged that she filed complaints with her supervisor, coworkers, and her employer's attorneys. ${ }^{105}$ The court concluded that filing complaints is not the kind of activity protected under section $510 .^{106}$

The court then addressed the decisions of the Ninth and Fifth Circuits in Hashimoto and Anderson. ${ }^{107}$ The court found the reasoning in Anderson unpersuasive because that court "merely recited section 510 without even addressing the facial inapplicability...to intra-office complaints.” 108 The court found the Hashimoto reasoning equally unpersuasive, even though Hashimoto at least recognized the inapplicability of the statute to internal complaints. ${ }^{109}$ According to the court, Hashimoto rejected the most compelling interpretation of section 510 in favor of a "fair" interpretation-construing the statute to protect persons who voice internal complaints. ${ }^{110}$ Thus, the Fourth Circuit would not extend section 510 to internal complaints because such an interpretation was not warranted under the language of the statute.

In Nicolaou v. Horizon Media, Inc., the Second Circuit was the next to rule on the issue of internal complaints. ${ }^{111}$ The plaintiff, Nicolaou, worked for the defendant employer as its director of human resources. ${ }^{112}$ Nicolaou discovered that the company had underfunded its 401(k) plan for over a decade. ${ }^{113}$ She brought this problem to the attention of various supervisors but soon became convinced that her employer was unwilling to address the problem. ${ }^{114}$ Nicolaou contacted an attorney for her

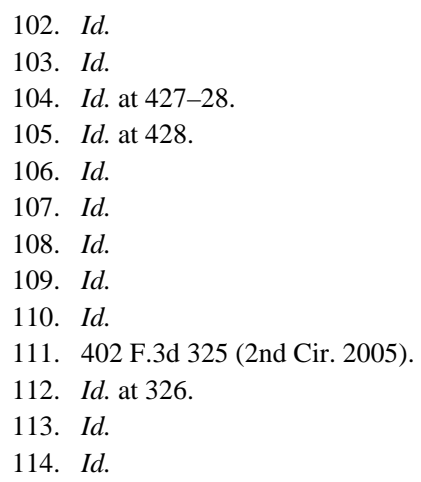


employer, who conducted her own investigation into the problem and confirmed Nicolaou's finding. ${ }^{115}$ She then had another meeting to discuss the issue with the president of the company. ${ }^{116}$ Nicolaou asserted that after this meeting a "campaign of retaliation" began against her, culminating in her termination. ${ }^{117}$ She filed suit against her former employer specifically alleging a violation of section 510 of ERISA. ${ }^{118}$

In examining Nicolaou's section 510 claim, the Second Circuit began by comparing the language of that statute with other similar federal whistleblower provisions. ${ }^{119}$ This comparison was short, with little attention paid to how courts have interpreted these similar statutes. $^{120}$ Rather than focusing on a comparison of the federal whistleblower statutes, the court—much like the Fourth Circuit-based its decision on the "plain" language of section $510 .{ }^{121}$

The Second Circuit may have reasoned that a comparison of case law interpreting section 510 of ERISA and other similar statutes such as the FLSA was unnecessary because it found the language of section 510 of ERISA unambiguously broader than the language of the FLSA statute. ${ }^{122}$ Section 510 contains the term inquiry; by contrast, the FLSA statute only contains the term proceeding. ${ }^{123}$ The court reasoned that the inclusion of inquiry to section 510 of ERISA manifests Congress's intent to protect those employees involved in the informal gathering of information. ${ }^{124}$ Thus, section 510 protects the informal gathering of information because it is within the plain meaning of inquiry.

Applying this reasoning to the facts of Nicolaou, the court concluded that if Nicolaou could prove that the president of the company contacted her to obtain information regarding the alleged underfunding of the plan, then section 510 would protect the action. ${ }^{125}$ The court reversed and remanded the case to determine if such contact occurred. ${ }^{126}$

\footnotetext{
115. Id.

116. Id.

117. Id.

118. Id. at 327.

119. Id. at 327-29.

120. See id. at 328.

121. Id.

122. Id.

123. Id.

124. Id. at 328-29.

125. Id. at 330 .

126. Id.
} 
The Second Circuit's interpretation of section 510 in Nicolaou appears to be far broader than the Fourth Circuit's. The court stressed, however, that its finding was not contrary to the Fourth Circuit's ruling. ${ }^{127}$ The court expressly agreed with the holding in King-section 510 protects something more formal than internal complaints, whether written or oral, to a supervisor. ${ }^{128}$ The Second Circuit, however, gave more weight to the term inquiry than the Fourth Circuit did. Given its reasoning in King, it seems unlikely that the Fourth Circuit would find that the meeting between Nicolaou and the president of the company connoted the level of formality requisite to garner section 510 protection. So while the Second and Fourth Circuits appear to agree that unsolicited internal complaints are not protected under section 510, their respective treatment of "solicited" complaints or information would most likely differ.

The Second Circuit's departure from the Fourth Circuit's reasoning is troubling for a number of reasons. First, the Second Circuit's reasoning calls for more judicial line-drawing than the Fourth Circuit's. When exactly does an "inquiry" begin? At what point in the process does an informal complaint cross the threshold into privileged and protected status? Further, the Second Circuit's interpretation of the term inquiry is likely to lead to absurd results. If an employee is protected once an informal investigation is conducted by his employer, what is to stop the employee from simply writing an anonymous letter detailing the alleged violations and then coming forward once the investigation has begun?

Judge Pooler's concurring opinion in Nicolaou raises another important point. Judge Pooler argued that because Nicolaou was a fiduciary of the plan, she had a burden to remedy perceived violations or face personal liability. ${ }^{129}$ Judge Pooler argued that placing that kind of burden on fiduciaries is evidence that ERISA's framers did not intend to leave fiduciaries unprotected. ${ }^{130}$ This indicates a strong argument that section 510 was intended to protect fiduciaries of ERISA plans. The focus of this Comment, however, is the broader issue of whether the section protects employees in general, not just those with fiduciary responsibilities.

127. Id.

128. Id.

129. Id. at 330-31 (Pooler, J., concurring).

130. Id. at 332 . 
The most recent circuit to weigh in on the split was the Third Circuit in Edwards v. A.H. Cornell \& Son, Inc. ${ }^{131}$ The plaintiff in the case, Edwards, asserted that she discovered numerous ERISA violations before her termination, including administering the group health plan on a discriminatory basis, lying to employees about the cost of group health insurance to dissuade them from opting into benefits, and enrolling noncitizens in ERISA plans by providing false social security numbers to insurance carriers. ${ }^{132}$ Edwards brought these complaints to management's attention and was fired shortly thereafter. ${ }^{133}$ The sole issue on appeal was whether ERISA's antiretaliation provision protected her internal complaints. ${ }^{134}$

In reaching its decision, the court first recounted the circuit split and the reasoning behind each circuit's decision. ${ }^{135}$ The court began its own analysis with its interpretation of the plain meaning of section 510. First, the court examined the surrounding words and provisions to determine if there was ambiguity in the statute. ${ }^{136}$ The court determined that the plain meaning of the term inquiry is "a request for information."137 Thus, to meet the terms of the statute, an employer must approach an employee and request information on possible ERISA violations. ${ }^{138}$ This is the same line of reasoning adopted by the Second Circuit. The fact that unsolicited complaints may result in an inquiry is not dispositive. ${ }^{139}$ The court also found that unsolicited complaints do not fit the plain definition of proceeding either. ${ }^{140}$ According to the court, a proceeding requires a more formal action such as the progression of a lawsuit or testimony in front of a tribunal. ${ }^{141}$

Similar to King and Nicolaou, the Third Circuit found persuasive the fact that Congress used narrower language for ERISA's whistleblower provision when broader language was available. ${ }^{142}$ However, the court relied on what it characterized as the "plain and unambiguous" language

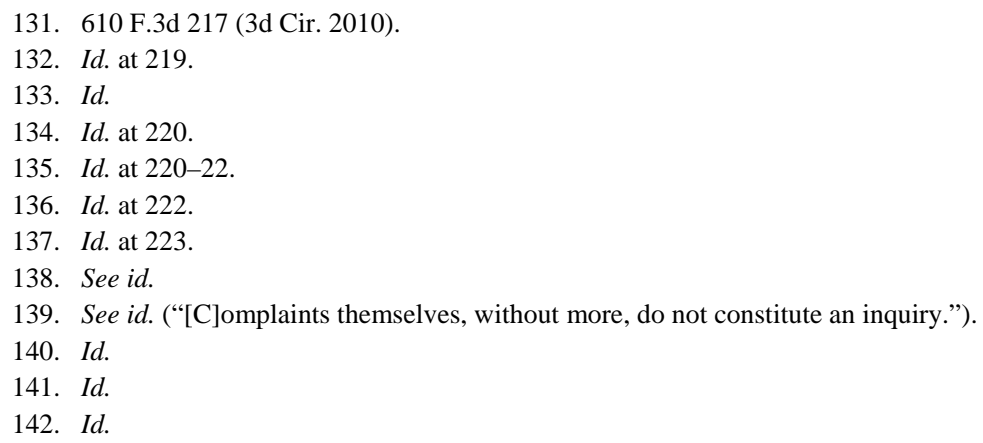


of the statute as the foundation of its reasoning. ${ }^{143}$ The Third Circuit noted that ERISA should be liberally construed and that "[i]f Section 510 were ambiguous, we would construe the provision in favor of plan participants." 144 However, the Third Circuit held that section 510-and subsequently Congress's intent-is not ambiguous. ${ }^{145}$ In so holding, the Third Circuit rejected Hashimoto's reasoning that failing to protect internal complaints undercuts the purpose of section $510 .{ }^{146}$ If Congress had wished to protect against such an event, according to the Third Circuit, it would have provided broader language in the provision. ${ }^{147}$

The dissenting opinion of Edwards by Judge Cowen presented the current argument of those in favor of protecting internal complaints. First, the dissent noted that section 510 of ERISA is a critical statutory safeguard. ${ }^{148}$ In support of this, the dissent cited Ingersoll-Rand Co. v. McClendon. ${ }^{149}$ In that case, the Supreme Court, analyzing section 510, stated: "Congress viewed this section as a crucial part of ERISA because, without it, employers would be able to circumvent the provision of promised benefits."150 Thus, in the dissent's view, the majority adopted an opinion that is inconsistent with common sense and therefore unsustainable. ${ }^{151}$ The dissent noted that the majority's arbitrary linedrawing on the issue of what inquiry means is likely to cause problematic results. ${ }^{152}$ For example, if an employee brings a complaint to management and during the conversation the manager asks several follow-up questions, is this now an "inquiry" protected under section 510 ? $^{153}$ The dissent believed that it would be odd to allow an employer to immediately fire an employee after she makes an informal complaint rather than initiating an investigation. ${ }^{154}$

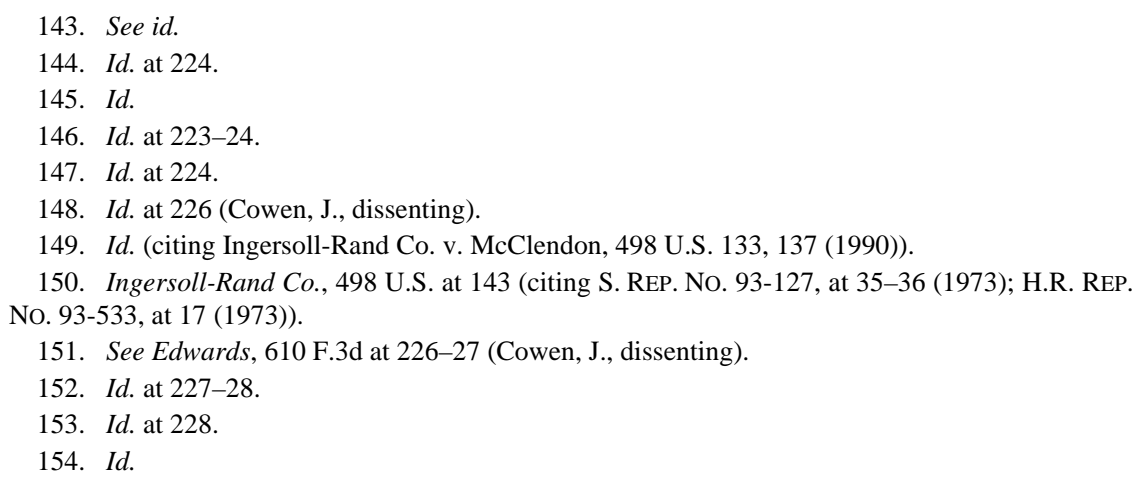


The dissent further argued that the majority's interpretation of the term inquiry leaves an entire class of employees unprotected. ${ }^{155}$ These employees have a "responsibility to conduct potentially sensitive and damaging investigations into possible ERISA violations" and need more protection than employees who simply answer a few questions. ${ }^{156}$ In light of all of this, the dissent believed that the language of section 510 is at the very least ambiguous and should thus be interpreted broadly to include "internal workplace complaints."157

\section{ANALYSIS}

The majority view that favors excluding unsolicited internal complaints from section 510 protection is correct, but for ultimately flawed and unsatisfying reasons. The dissenting opinion in Edwards did a nice job of highlighting this very point. The crux of the Second, Third, and Fourth Circuits' reasoning was that the language of section 510 of ERISA is unambiguous and plain. While the plain meaning of statutory words is often enough to resolve ambiguities and disagreements on statutory interpretation, in this case it is ultimately unsatisfying because it leads to a seemingly counter-majoritarian result. It seems remarkably unfair to say section 510 affords no protection for an employee acting selflessly for the good of the public. If the majority had expanded their analysis to explain why Congress would intend such a seemingly incongruous result, it would make their ultimate decision seem less harsh and more rational.

Of the three, the Third Circuit provided the most expansive basis for its opinion. The Edwards court noted repeatedly that the whistleblower protection statute is comparable to that of other federal provisions, except that it contains more narrowly construed language. ${ }^{158}$ However, the Third Circuit failed to make such a comparison the basis of its reasoning. Instead, it relied almost solely on the provisions' differing language to support its thesis that the statute is facially unambiguous.

Courts' reasoning should incorporate an extensive comparison of the federal whistleblower provisions and the case law interpreting them, rather than using them as perfunctory support for an unsatisfying

155. Id.

156. Id.

157. Id.

158. Id. at 222-25. 
conclusion. The circuits should have made their statutory interpretation only the first step of a three-step process. Therefore, a sounder and more satisfying explanation of the majority's conclusion results from examining (1) case law interpreting similar statutory provisions; (2) the legislative history and purpose of section 510 of ERISA compared with that of other, broader provisions such as Title VII; and, finally, (3) the underlying rights protected by section 510 of ERISA balanced against the opposing interests of employers.

\section{A. Case Law Interpreting Similar Whistleblower Provisions}

Title VII of the Civil Rights Act of 1964 contains a whistleblower provision similar to section 510 of ERISA. This provision protects employees who have "participated in any manner in an investigation, proceeding, or hearing under this subchapter."159 This is a "participation clause" and is common in federal whistleblower protection statutes. ${ }^{160}$ The purpose behind such a clause is that employee participation in investigations and hearings is essential to proper enforcement of federal statutes. ${ }^{161}$ Courts construe participation clauses very broadly. ${ }^{162}$ For example, courts construe the clause to protect employees who file suits against both former and current employers. ${ }^{163}$ However, the participation clause is not the tool courts use to protect employees who make unsolicited internal complaints.

Several federal whistleblower protection statutes contain an "opposition clause" as well as a participation clause. ${ }^{164}$ These opposition clauses typically make it unlawful to discriminate against any employee who has opposed a practice made unlawful by the federal act. ${ }^{165}$ These clauses, however, are less typical than participation clauses and have been construed both narrowly-to protect employees who testify in

159. 42 U.S.C. § 2000e-3(a) (2006) (emphasis added); see also Age Discrimination in Employment Act of 1967 § 4(d), 29 U.S.C. § 623(d) (protecting employees who have "participated in any manner in an investigation, proceeding, or litigation under this chapter").

160. WESTMAN \& MODESITT, supra note 4, at 191-92.

161. Id. at 191.

162. See id. at 191-92.

163. Id. at 192.

164. See, e.g., 42 U.S.C. § 2000e-3(a) ("It shall be an unlawful employment practice for an employer to discriminate against any of his employees... because he has opposed any practice made an unlawful employment practice by this subchapter ....”); 29 U.S.C. § 623(d) (containing similar language).

165. See id. 
enforcement proceedings-and broadly-to protect employees who make flippant remarks to and around their superiors. ${ }^{166}$ Thus, courts have generally protected employee conduct under opposition clauses so long as it is reasonable. ${ }^{167}$

An example of the breadth of opposition clauses is found in the Fourth Circuit's decision in Armstrong $v$. Index Journal Co. ${ }^{168}$ Armstrong held that Title VII's antiretaliation provision protects internal complaints made to management in a nondisruptive manner. ${ }^{169}$ The plaintiff complained to management on numerous occasions about her job classification and the differences in pay between categories of employees. ${ }^{170}$ These internal complaints led to her termination. ${ }^{171}$ She subsequently filed a complaint with the Equal Employment Opportunity Commission (EEOC) and initiated an action against her former employer. $^{172}$

In assessing Armstrong's retaliation complaint, the court first noted that under Title VII's whistleblower protection statute it is unlawful for an employer to discriminate against an employee "because he has opposed any practice made an unlawful employment practice." ${ }^{\text {173 }}$ The court stated that an employee's behavior need not be a formal action against their employer in order to gain protection under the statute. ${ }^{174}$ Rather, the court expressly interpreted the opposition clause "to encompass informal protests, such as voicing complaints to employers or using an employer's grievance procedures."175 The court concluded that Armstrong was incontrovertibly discharged because she "opposed practices made unlawful by the Act." "176

The court in Armstrong did not base any of its analysis or reasoning on the participation clause of Title VII. In fact, there is no need to do so. Courts consider the opposition clause broad enough to encompass the

166. WESTMAN \& MODESITT, supra note 4, at 192.

167. Nicholas M. Strohmayer, Note, Drawing the Line: Niswander's Balance Between Employer Confidentiality Interests and Employee Title VII Anti-Retaliation Rights, 95 IOWA L. REV. 1037, 1041 (2010).

168. 647 F.2d 441 (4th Cir. 1981).

169. Id. at 448 .

170. Id. at 444 .

171. Id.

172. Id.

173. Id. at 448.

174. Id.

175. Id.

176. Id. at 449. 
activity in which the plaintiff engaged. Seen in this light, the inclusion by Congress of both an opposition and a participation clause in the statute encompasses and protects as much employee conduct as possible. The participation clause protects employees engaged in more formal proceedings or complaints. By contrast, the opposition clause protects employees from being retaliated against for availing themselves of their employers' internal dispute resolution mechanisms. The opposition clause encourages employees to bring unlawful practices to the attention of their supervisors so that the violation may be resolved without the need for litigation. Therefore, the opposition clause by design protects a wider variety of activity than the participation clause would be able to do alone.

The broad nature of the opposition clause was also evident in CarterObayuwana v. Howard University. ${ }^{177}$ There, a tenured university professor issued a memorandum that accused her supervisor of having a "sexist mentality" against her. ${ }^{178}$ Supervisors in both her department and the administrative offices of the university received copies of the memo. ${ }^{179}$ The department attempted to resolve the issue through several failed attempts at mediation. ${ }^{180}$ The plaintiff then sued her employer, alleging Title VII violations. ${ }^{181}$

The court held that to prove a prima facie case of retaliation under Title VII's opposition clause, the plaintiff must show (1) that she was engaged in the protected activity; (2) that her employer took an adverse employment action against her, such as demotion or termination; and (3) a nexus existed between steps one and two. ${ }^{182}$ The court then sought to determine whether the plaintiff's memo constituted protected activity within the meaning of the statute. ${ }^{183}$ Whereas the trial court had found that the plaintiff did not engage in protected activity until she contacted an enforcement agency, the appellate court found that writing the memo constituted protected activity under the opposition clause. ${ }^{184}$ The court reasoned that activity need not be in the form of a formal complaint for

177. 764 A.2d 779 (D.C. 2001).

178. Id. at 782 .

179. Id.

180. Id.

181. Id. at 785 .

182. Id. at 790 (citing McKenna v. Weinberger, 729 F.2d 783, 790 (D.C. Cir. 1984)).

183. Id.

184. Id. at 790-91. 
Title VII's opposition clause to protect it. ${ }^{185}$ Thus, the protection of the opposition clause extends to employees' informal complaints to their superiors within the business. ${ }^{186}$ This protection extends even when the complaint, as it did here, fails to employ “'magic words' such as 'discrimination.”,187 Thus, plaintiff's first memorandum accusing her supervisor of having a "sexist mentality" towards her was enough to gain protection from retaliation under Title VII's opposition clause. ${ }^{188}$

This case is indicative of the expansive breadth of an opposition clause within a federal whistleblower statute. The plaintiff made a series of escalating complaints to her supervisors, but the court concluded that she had done enough to gain the protection of the statute simply by promulgating a memorandum containing a litany of unsupported accusations against her immediate supervisor.

The Age Discrimination in Employment Act of 1967 (ADEA) contains an opposition clause similar to the one contained in Title VII. ${ }^{189}$ For example, in Rufo v. Dave \& Buster's, Inc., the plaintiff complained that he was fired in retaliation for making internal complaints about age discrimination. ${ }^{190}$ Rufo felt that the promotion of a less qualified manager above him "amounted to age discrimination in violation of the ADEA."191 Similar to a Title VII claim, the court reasoned that to establish a prima facie case under the ADEA, Rufo must first show that he was engaged in protected activity. ${ }^{192}$ In this instance, Rufo, the defendant, and the court all agreed that filing an internal complaint of age discrimination was a protected activity under the ADEA's opposition clause. ${ }^{193}$

These cases are important for analysis because they present factual scenarios similar to those facing courts deciding whether to apply section 510 of ERISA to internal complaints. The cases are indicative of the fact that in various statutes Congress has provided a provision broad enough to encompass and protect an array of employee activity-a statutory

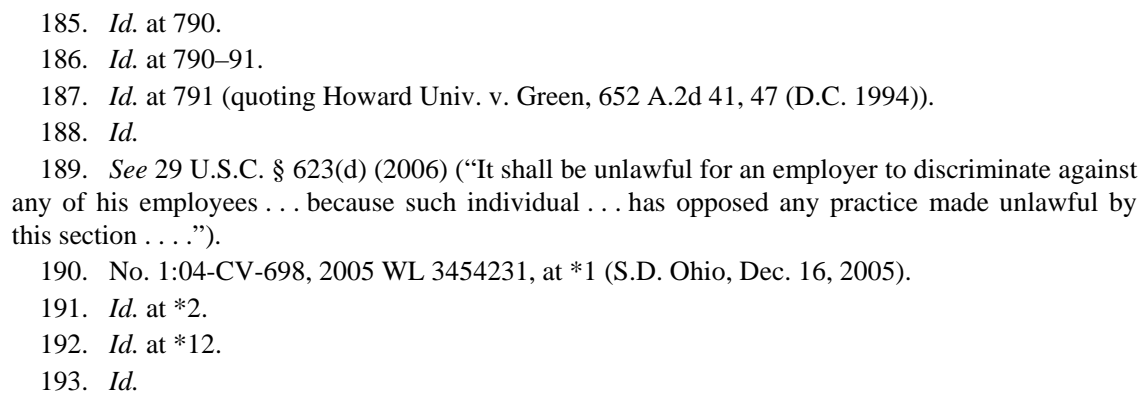


provision it declined to provide employees in ERISA. One must consider the underlying rights protected by the acts to reach an explanation for the inclusion of a broader provision in some federal statutes and not in others. It is possible that Congress desired to provide employees more protection and incentive to blow the whistle against employers who discriminate based upon immutable characteristics than against those who may be committing ERISA violations. In other words, the act of balancing employer rights and interests versus employee rights and interests ${ }^{194}$ weighs more heavily in favor of employees under these statutes than it does under section 510 of ERISA.

Examining this balancing of interests creates a far more sustainable position than the majority circuits have adopted. Even if one can characterize the language of section 510 as ambiguous, the statutory language clearly still protects something less than those federal whistleblower statutes containing an opposition clause. The fact that Congress passed the Civil Rights Act of 1964 only a few years before ERISA and expressly included an opposition clause bolsters this point. If Congress had wanted to afford employees exercising their rights under ERISA the same level of protection as those exercising their rights under Title VII, it could have done just that. While the Second and Third Circuits acknowledged this fact, they needed to go further, making it the focal point of their reasoning and not just support for an unsatisfying interpretation of the statute.

\section{B. Comparative Legislative History: ERISA Versus Title VII}

The legislative histories for ERISA and Title VII's antiretaliation provision yield important insights into why one act protects internal complaints and the other does not. The purpose in examining the two histories is to discern the congressional intent and the legislative goal that the provisions were enacted to achieve. In examining the legislative history of each antiretaliation provision, one finds that Title VII was intended to achieve a far broader goal than section 510 of ERISA. To this end, Title VII requires a more expansive and protective whistleblower statute. By contrast, section 510 of ERISA was intended to achieve a far narrower goal, and therefore contains a more narrowly tailored antiretaliation statute.

194. See Fisher et al., supra note 26, at 133-34; Ramirez, supra note 25, at 224. 
Title VII was an effort by the federal government to eliminate all employment discrimination based on race, color, religion, sex, or national origin. ${ }^{195}$ While the legislative history on Title VII's antiretaliation provision is relatively sparse, courts have consistently interpreted it as providing exceptionally broad protections with the objective of ensuring employees have unmitigated access to the remedies provided by the act. ${ }^{196}$ Furthermore, courts often look to the EEOC-the agency charged with enforcing Title VII-for help in interpreting the statute. $^{197}$ The EEOC has noted that the enforcement of Title VII is dependent upon the willingness of individuals to voice opposition to employment discrimination. ${ }^{198}$ It is therefore imperative that employees be able to voice complaints and opposition without fear that their employers will take retaliatory action against them. ${ }^{199}$ Otherwise, the goal of Title VII's retaliatory provision-to ensure that employees exercise their rights in order to eliminate workplace discriminationcannot be achieved. ${ }^{200}$

By contrast, ERISA serves a much narrower purpose. ERISA largely deals with private plans where the focus is on individual investment decisions. ${ }^{201}$ The goal of ERISA is to ensure the security of these investments. ${ }^{202}$ It is readily apparent that this is a far narrower goal than that of Title VII.

Although the legislative history behind ERISA's antiretaliation provision deals largely with the first sentence of section 510, one can still glean some important insight from its interpretation. In interpreting section 510, the Supreme Court has held that Congress's intent was to "protect[] plan participants from termination motivated by an employer's desire to prevent a pension from vesting.,"203 This assertion is bolstered by a Senate report on the antiretaliation provision, which the Supreme Court relied on in interpreting congressional intent behind section $510:^{204}$

195. BNA Operations Manual, The Civil Rights Act of 1964: TeXt, Analysis, and LEGISLATIVE HISTORY 1 (1964).

196. Oren R. Griffin, Avoiding Retaliation in the Higher Education Workplace in the Aftermath of Burlington N. \& Santa Fe Ry. Co. v. White, 227 EdUC. L. REP. 525, 526-27 (2008).

197. Id. at 526 .

198. Id. at 527.

199. Id.

200. Id. at 526.

201. See Befort, supra note 47, at 946.

202. See WoOtEn, supra note 44 , at 3.

203. Ingersoll-Rand Co. v. McClendon, 498 U.S. 133, 143 (1990).

204. Id. (citing S. REP. NO. 93-127, at 35-36 (1973); H.R. REP. No. 93-533, at 17 (1973)). 
These provisions were added by the Committee in the face of evidence that in some plans a worker's pension rights or the expectations of those rights were interfered with by the use of economic sanctions or violent reprisals. Although the instances of these occurrences are relatively small in number, the Committee has concluded that safeguards are required to preclude this type of abuse from being carried out and in order to completely secure the rights and expectations brought into being by this landmark reform legislation. ${ }^{205}$

According to the Supreme Court in Ingersoll-Rand Co. V. McClendon, that case presented the exact factual scenario Congress had in mind when enacting section 510. ${ }^{206}$ In Ingersoll-Rand Co., an employee was fired four months before his pension was set to vest. ${ }^{207}$ The employee alleged that the primary reason for his termination was the company's desire to avoid contributing to his pension fund. ${ }^{208}$ This factual scenario is further evidence that Congress's goal in enacting section 510 was narrower than Title VII's antiretaliation provision.

The legislative history of each act makes it clear that the antiretaliation provisions of section 510 and Title VII are meant to achieve different goals. Title VII's antiretaliation provision is meant to encourage employees to voice their opposition to discrimination without fear of reprisal. It is representative of Congress's goal that employees should feel completely free to access the statute's remedial measures to eliminate workplace discrimination. It is clear then what purpose the inclusion of an opposition clause serves. Without an opposition clause, the primary purpose of the provision would be easily circumvented and its inclusion would be almost useless. If an employer fires an employee the second she makes a complaint regarding alleged discrimination, she probably will not feel free to access Title VII's remedial measures. Indeed, she may never get the chance, as her employer could terminate her shortly after voicing any displeasure. Workplace discrimination would continue to be a problem because opposing it would result in swift reprisal. Thus, the opposition clause was purposely included to broaden the effect of the statute. It provides remarkably broad protections to achieve a remarkably broad goal.

205. S. REP. No. 93-127, at 35.

206. Ingersoll-Rand Co., 498 U.S. at 143 ("We have no doubt that this claim is prototypical of the kind Congress intended to cover under $\S 510$.”).

207. Id. at 135.

208. Id. at $135-36$. 
On the other hand, the legislative history of section 510 of ERISA reveals that its goal is more specific and narrowly tailored when compared to that of Title VII. Congress wanted to ensure the security of private pension plans. The key word to focus on is private. These plans involve the personal decisions of individuals and their employers regarding the employee's future income. It is possible that Congress did not want to burden these decisions with an overbearing regulatory scheme and therefore provided a more narrowly tailored provision to enforce it. Had Congress's goal been broader-as it was in Title VII-it would undoubtedly have provided a more expansive provision to achieve the goal.

Furthermore, an opposition clause is not integral to ERISA the way that it is to Title VII. Title VII requires employees to be forthcoming and make internal complaints both to bring discrimination to the attention of authorities and to prove that the alleged discrimination took place. By contrast, the willingness of employees to be forthcoming in an ERISA context is not as important for two reasons. First, as Judge Pooler noted in Nicolaou, ERISA makes plan fiduciaries personally liable for breaching any of their obligations or responsibilities under the plan. ${ }^{209}$ This liability includes failing to remedy perceived improprieties. ${ }^{210}$ Because of this, ERISA fiduciaries have a duty to report violations. ${ }^{211}$ Consequently, the enforcement of ERISA is not as dependent upon internal complaints the way that Title VII is because there is an internal mechanism for reporting violations. Second, as stated earlier, ERISA has substantial reporting and recordkeeping requirements. ${ }^{212}$ In light of this, once a violation is made, the information necessary to prove that violation is likely contained within those records. The cooperation and participation of employees affected by the violation may not even be necessary to prove the violation. Thus, where internal complaints play an integral part in the enforcement of Title VII, they are arguably not necessary either to monitor or enforce ERISA.

By contrast, the participation clause helps ERISA and section 510 to achieve its goal in an important way. Namely, a participation clause

209. Nicolaou v. Horizon Media, Inc., 402 F.3d 325, 330 (2d Cir. 2005) (Pooler, J., concurring); see also 29 U.S.C. § 1109(a) (2006).

210. See Nicolaou, 402 F.3d at 331 (Pooler, J., concurring) (stating that to avoid personal liability a fiduciary is strongly encouraged to remedy improprieties).

211. See id.

212. See 29 U.S.C. § 1059 (2006 \& Supp. III 2010) (listing the recordkeeping and reporting requirements of employers). 
encourages those who do participate in a formal inquiry or proceeding to do so truthfully and honestly without fear of reprisal. A participation clause alleviates employees' fear that their truthful testimony will result in reprisal from their employer. Thus, protecting these employees from retaliation promotes truthfulness in testimony and helps legitimate claims sought to be protected by section 510 succeed.

Thus, the legislative history of section 510 of ERISA shows that it was enacted to achieve a narrow goal. While a participation clause helps this goal to be achieved, it can easily be accomplished without the need for the expansive protection of an opposition clause. In light of this, the majority view favoring no protection for unsolicited internal complaints is supported by the legislative history of ERISA.

\section{Balancing the Underlying Right Protected Against Legitimate Employer Interests}

Even considering all of the prior analysis, the exclusion of internal complaints from section 510 protection still seems counter-majoritarian. To hold that employees who act selflessly to remedy real or perceived violations have no remedy under the law seems draconian. To understand why internal complaints are not protected, one must again consider that Congress has other goals in mind in constructing whistleblower protections than solely providing remedies for retaliation. The significant cost, financial and otherwise, that whistleblower protection inflicts upon employers necessitates balancing public policy goals against legitimate employer interests. ${ }^{213}$ Thus, whistleblower provisions correlate to the importance of the right protected by the underlying statute.

For example, as was discussed above, Title VII's purpose is to achieve a very broad and expansive goal-eliminating workplace discrimination based upon race. ${ }^{214}$ The root causes and underlying motivations of Congress in creating this legislation are traceable to the very beginnings of the country in the Declaration of Independence's assertion that all persons are created equal. ${ }^{215}$ Likewise, Title VII is a recognition that characteristics such as race are immutable and "utterly

213. See Fisher et al., supra note 26, at 133-34; Ramirez, supra note 25, at 224.

214. BNA OPERATIONS MANUAL, supra note 195, at 1.

215. Id. at 17 . 
irrelevant to employment decisions." ${ }^{216}$ In this light, it is easy to see how the underlying purpose and rights protected by Title VII trump even legitimate employer concerns over cost and workplace unity. Employers may have a right to make managerial decisions without interference from the federal government, but when those decisions result in discrimination against employees for characteristics wholly unrelated to any legitimate employment decision, Title VII allows and encourages federal intrusion to correct the injustice. Furthermore, because racial discrimination is often attributable to insidious and evil prejudices and predispositions, Congress is justified in providing employers with less latitude in making employment decisions. ${ }^{217}$ By contrast, when there are reasonable bases for employment decisions, managers have more latitude and leeway in making them. ${ }^{218}$

ERISA seeks to regulate employers' handling of employer-sponsored private pension systems. ${ }^{219}$ This type of regulation differs facially from Title VII in several respects. First, the mishandling of private pension funds does not stem from insidious predispositions the same way that racial discrimination does. Therefore, the whistleblower protection provision in the ERISA context should balance more favorably toward the employer. Similarly, decisions regarding employee funds and contribution systems are closely related to the functions and kinds of decisions managers are in charge of in a business. By contrast, a person's race or religious beliefs are entirely unrelated to management. Because ERISA decisions may relate to legitimate managerial concerns, it seems natural that employers would have more latitude in making those decisions.

Thus, while the regulation of pension interests is an important concern of Congress, it does not seem to necessitate the same level of government intrusion as the regulation of workplace discrimination. Because of this, employers have a better argument that the minority circuits' expansive and broad whistleblower protection does more harm than good by forcing them to expend time and money defending greater numbers of allegations and charges from employees, all while intruding

216. See United Steelworkers of Am. v. Weber, 443 U.S. 193, 228 n.10 (1979) (Rehnquist, J., dissenting).

217. See Anne Marie Tracy \& Norma Skoog, Is Business Judgment a Catch-22 for ADEA Plaintiffs? The Impact of Smith v. City of Jackson on Future ADEA Employment Litigation, 33 U. DAYTON L. REV. 231, 254 (2008).

218. See id.

219. Wooten, supra note 44 , at 1. 
on the employer's ability to make legitimate managerial decisions and run their business as they see fit. The majority circuits' limited protection better balances the interests of employers with those of the public. The majority achieves this balance by ensuring a cause of action for those whose employers interfere with their pension rights and freeing employers from the cost of having to investigate and defend every claim for wrongful discharge brought under section 510 of ERISA. Thus, the broader section 510 protection advocated by the minority circuits does not adequately account for the legitimate interests of employers, whereas the majority circuit's view does account for such interests.

\section{CONCLUSION}

In conclusion, if whistleblower statutes seek to attain some balance between the rights of employees and the interests of employers, it would appear that in this instance the interests weigh in the favor of the latter. Of the five circuits to address the issue, three have determined that section 510 does protect internal complaints. While these circuits ultimately came to the correct conclusion, their reasoning remains suspect. All three circuits based their decisions on the "plain language" within section 510 of ERISA. The circuits concluded that the terms inquiry and proceeding do not encompass an internal complaint given to management. This argument, however, results in arbitrary line-drawing and fails to sustain itself in the face of convincing criticism. How can the statute allow for such a seemingly unjust result? How can the language be both perfectly clear and yet the subject of a split amongst the circuits? The better argument calls for making statutory interpretation a mere component of a broader three-part analysis. The basis of this analysis is an intensive comparison of ERISA's whistleblower provision with those contained in similar federal acts. When one does this, it becomes clear that those statutes protecting internal complaints do so explicitly, and Congress's exclusion of internal complaints from section 510 of ERISA is purposeful. Further support for this proposition comes from examining the legislative history of section 510 and comparing it with that of Title VII. The goals these statutes attempt to achieve differ significantly in both their purpose and their breadth. Title VII's purpose is far broader in scope than ERISA and relies heavily on the willingness of employees to speak out against discriminatory practices. Therefore, Title VII needs a broader whistleblower provision to achieve its purpose. By contrast, ERISA's purpose is narrower and not as dependent on the willingness of individuals to be forthcoming to pursue it. Therefore, 
ERISA's whistleblower provision is narrow, and the protection of internal complaints is not as necessary. Finally, there is a good argument that the amount of protection afforded employees in antiretaliation statutes correlates directly to the importance of the rights they protect. Again, Title VII protects employees from discriminatory practices. An employee's right not to be treated differently based on their race or ethnicity is an important one that requires extraordinarily broad protection. By contrast, ERISA protects the security of employees' retirement-an important goal but arguably less important than that of Title VII. In this light, the whistleblower provision within ERISA is narrower because it correlates to the right protected by that Act. Thus, even if section 510 is ambiguous, a fair interpretation still does not afford protection of internal complaints. 